\title{
EFFECT OF HUMAN RESOURCES COMPETENCE ON THE GROWTH OF SEPSIS PREMATURE INFANTS THROUGH THE PREPARING AND ADMINISTRATION OF PARENTERAL NUTRITION IN HAJI ADAM MALIK HOSPITAL
}

\author{
VIVI ASFIANTI ${ }^{1,2 *}$, ROSIDAH ${ }^{3}$, GUSLIHAN DASA TJIPTA ${ }^{4}$ \\ ${ }^{1}$ Departement of Pharmacology, Faculty of Pharmacy, Universitas Sumatera Utara, Medan, Indonesia. ${ }^{2}$ Departement of Pharmacology, \\ Faculty of Pharmacy, University of Sari Mutiara Indonesia, Medan, Indonesia. ${ }^{3}$ Departement of Pharmacology, Faculty of Pharmacy, \\ Universitas Sumatera Utara, Medan, Indonesia. ${ }^{4}$ Department of Paediatric, Faculty of Medicine, Universitas Sumatera Utara, Medan, \\ Indonesia. Email: vivi.asfianti@yahoo.com
}

Received: 07 March 2018, Revised and Accepted:25 March 2018

\begin{abstract}
Objective: This research was carried out to determine the effect of knowledge competence and skills on the preparing and administration of carbohydrates and protein in parenteral nutrition, to determine the effect of the preparing and administration of carbohydrates and protein in parenteral nutrition on the growth of sepsis premature infants.
\end{abstract}

Methods: The method used was observational analytic using path analysis. The study population was 25 sepsis premature infants who received parenteral nutrition and human resource preparing and administration of parenteral nutrition.

Results: The research results showed knowledge competence and skill simultaneously does not have a significant effect on the preparing and administration of carbohydrates and protein in parenteral nutrition, knowledge competence, and skills on the preparing and administration of carbohydrates and proteins simultaneously does not have a significant effect on the growth of sepsis premature infants. Knowledge competence partially has significant effect on the administration and preparing of carbohydrate in parenteral nutrition on the growth of sepsis premature infants.

Conclusion: This research showed the human resources competence does not have effect on the growth of sepsis premature infants through the preparing and administration of parenteral nutrition.

Keywords: Sepsis premature infants, Parenteral nutrition, Knowledge, Skills.

(c) 2018 The Authors. Published by Innovare Academic Sciences Pvt Ltd. This is an open access article under the CC BY license (http://creativecommons. org/licenses/by/4. 0/) DOI: http://dx.doi.org/10.22159/ajpcr.2018.v11s1.26572

\section{INTRODUCTION}

The birth of low birthweight (LBW) premature infants or LBW premature is the main social economic public health in developed and developing countries. Preterm birth in the world attains \pm 13 million infants/year which is around 9.6\% of all births [1]. Starting in 1990 until 2010 an increase in the incidence number of preterm birth and Indonesia is ranked fifth in a row of 10 countries that contribute $60 \%$ of preterm birth in the world. The birth number for neonates in Indonesia is $11.1 \%$ [2].

The premature infant is infant born with a gestational age $\leq 37$ weeks with LBW that is $<2500 \mathrm{~g}$ [3]. Optimal administration of nutrition in premature infants is critical and determines the success of the next growth develop of infant. Infant who not getting enough nutrients will have impaired brain growth and the risk of permanent brain damage. To achieve optimal growth and development of premature infants, infants should receive fluid, electrolytes, calories, fats, vitamins, and minerals according to their needs [4]. One of the efforts undertaken to grow and develop optimally is administration of parenteral nutrition.

Parenteral nutrition is nutrient administration through intravenously. Parenteral nutrition is given to individual who cannot accept nutrient intake through enteral or oral [5]. Parenteral nutrition is included in high alert containing a number of pharmaceutical active substances [6]. Administration of parenteral nutrition is the main supporting means of severe pain infants treatment or LBW infants treated in the neonatal intensive care unit. The often challenge encountered in the implementation of parenteral nutrition is limited equipment, trained personnel, and the differences in standards in each health center [7]. Preparation of parenteral nutrition is one of the sterile dispensing activities, namely, parenteral nutrition mixing activities were carried out by trained human resources in aseptic according to the needs of patients with maintaining the stability of the preparation, standard formula, and adherence with the accompanies procedure. Implementation of parenteral nutrition requires trained human resources, facilities, and equipment as well as specifically handling procedures [7].

\section{METHODS}

This research was carried out in Perinatology units of Haji Adam Malik Hospital with a population study involved was 25 sepsis premature infants who received parenteral nutrition and human resource preparing and administration of parenteral nutrition. The method used was observational analytic [8,9] with data analysis techniques using path analysis [10].

\section{RESULTS}

Path analysis

The relation of knowledge competence and skills on the preparing and administration of carbohydrates

Fig. 1 describes the relation of knowledge competence and skills on the preparing and administration of carbohydrates.

The relation of knowledge competence and skills on the preparing and administration of protein

Fig. 2 describes the relation of knowledge competence and skills on the preparing and administration of protein. 


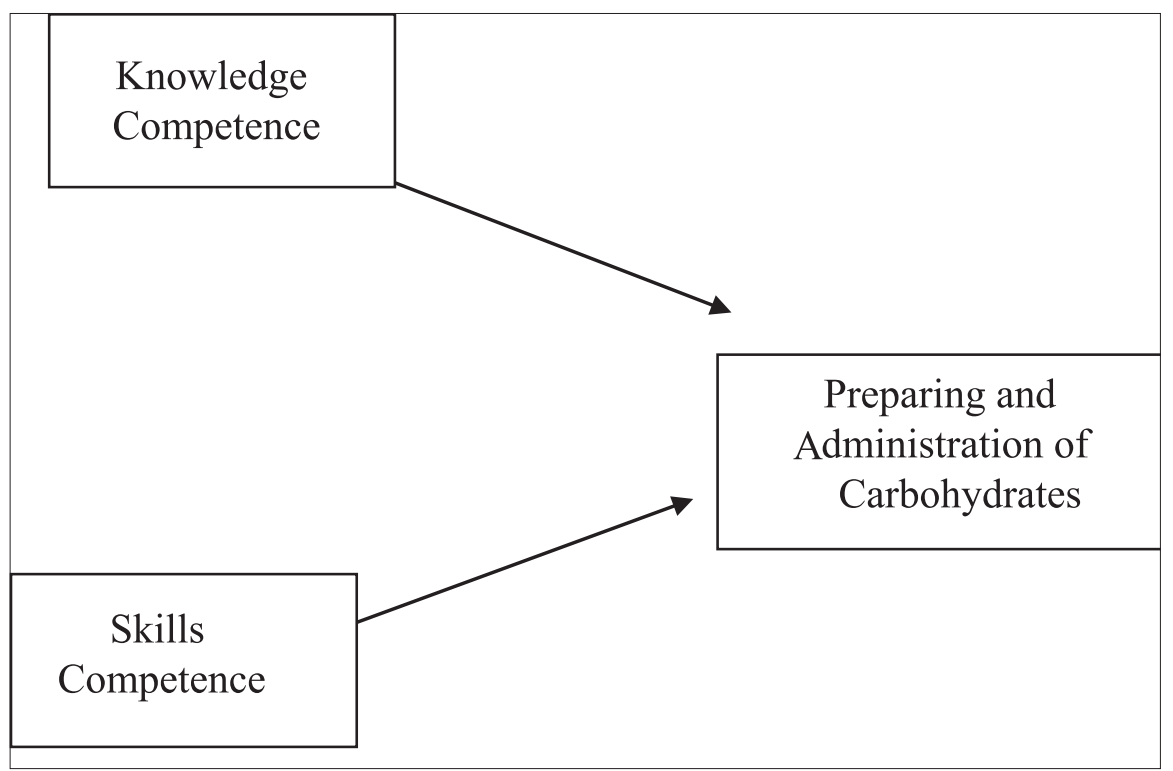

Fig. 1: Substructure 1 the effect of knowledge competence and skills on the preparing and administration of carbohydrates in path analysis

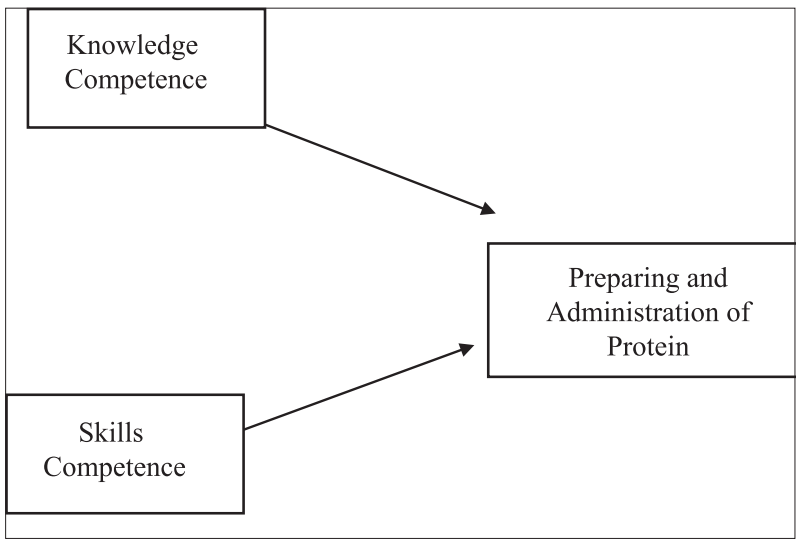

Fig. 2: Substructure 1 the effect of knowledge competence and skills on the preparing and administration of protein in path analysis

Table 1: Partial hypothesis test of the effect of knowledge competence and skills on the preparing and administration of carbohydrates

\begin{tabular}{lll}
\hline Variable & $\mathbf{T}$ & $\mathbf{p}$ \\
\hline Constant & 0.728 & 0.474 \\
Knowledge competence & 2.282 & 0.033 \\
Skills competence & -1.917 & 0.068 \\
\hline
\end{tabular}

Partially analysis of the effect of knowledge competence and skills on the preparing and administration of carbohydrates and protein on the growth of sepsis premature infants

Table 3 shows partial hypothesis test of the effect of knowledge competence and skills on the preparing and administration of carbohydrates and protein on the growth of sepsis premature infants.

\section{DISCUSSION}

Based on Table 1, the value of $p$ value on knowledge competence variable is 0.033 , it can be argued that ${ }^{*} \mathrm{p}<0.05$, it means there is a significant effect between knowledge competence on human resources
Table 2: Partial hypothesis test of the effect of knowledge competence and skills on the preparing and administration of protein

\begin{tabular}{lll}
\hline Variable & $\mathbf{T}$ & $\mathbf{p}$ \\
\hline Constant & 0.028 & 0.978 \\
Knowledge competence & 1.127 & 0.272 \\
Skills competence & -0.622 & 0.541 \\
\hline
\end{tabular}

Table 3: Partial hypothesis test of the effect of knowledge competence and skills on the preparing and administration of carbohydrates and protein on the growth of sepsis premature infants

\begin{tabular}{lll}
\hline Variable & $\mathbf{T}$ & $\mathbf{p}$ \\
\hline Constant & 4.826 & 0.000 \\
Knowledge competence & -1.758 & 0.095 \\
Skills competence & 0.549 & 0.589 \\
Administration of carbohydrates & 2.174 & 0.043 \\
Administration of protein & -1.358 & 0.190 \\
\hline
\end{tabular}

ability in preparing and administration of carbohydrates on sepsis premature infants. The value of $p$ value on the skills competence is 0.068 , it can be argued that ${ }^{*} p>0.05$, it means there is no significant effect between knowledge competence on human resources ability in preparing and administration of carbohydrates on sepsis premature infants.

Based on Table 2, the value of $\mathrm{p}$ value on knowledge competence and skills variable is 0.272 , it can be argued that ${ }^{*} p>0.05$, it means there is no significant effect between knowledge competence on human resources ability in preparing and administration of protein on sepsis premature infants. The value of $p$ value on skills competence variable is 0.541 , it can be argued that $* p>0.05$, it means there is no significant effect between skills competence on human resources ability in preparing and administration of protein on sepsis premature infants.

Based on Table 3, the value of $p$ value on knowledge competence and skills variables is 0.095 and 0.589 , it can be argued that ${ }^{*} \mathrm{p}>0.05$, it means there is no significant effect between knowledge competence 
and skills on the growth of sepsis premature infants was carried out in Haji Adam Malik Hospital. The value of $\mathrm{p}$ value on preparing and administration of carbohydrates variable is 0.043 , it can be argued that ${ }^{*} \mathrm{p}<0.05$, it means there is a significant effect between preparing and administration of carbohydrates on the growth of sepsis premature infants. The value of $\mathrm{p}$ value on preparing and administration of protein variable is 0.190 , it can be argued that ${ }^{*} p>0.05$, it means there is no significant effect between preparing and administration of protein on the growth of sepsis premature infants.

\section{CONCLUSION}

The conclusions of this research are human resources competence (knowledge and skills) does not have effect on the growth of sepsis premature infants through the preparing and administration of parenteral nutrition.

\section{CONFLICTS OF INTERESTS}

We declare that there is no conflict of interest.

\section{AUTHORS CONTRIBUTION}

All authors equally contributed.

\section{REFERENCES}

1. National Report on Basic Health Research (RISKESDAS). Indonesia's Ministry of Health; 2010. p. 5-7.

2. Basic Guidelines on Sterile Dispensing. Directorate General of Pharmacy and Health Tools Indonesia's Ministry of Health; 2009;1:7-16

3. Department of Pediatrics Faculty of Medicine University of Indonesia. Integrated Child Health Services. Yogyakarta: Department of Pediatrics Faculty of Medicine University of Indonesia; 2013. p. 214

4. Surasmi A, Handayani S, Kusuma H. High Risk Baby Care. Jakarta: EGC; 2003. p. 31

5. Widiasa P, Suandi I, Wayan R. Total parenteral nutrition in premature babies. Sari Pediatri 2007;9:39.

6. Harjodisastro D, Syam A, Sukrisman L. Nutrition Support in Case of Internal Disease. Vol. 1 Jakarta: Faculty of Medicine University of Indonesia; 2006. p. 4-31

7. Gomella TL. Neonatology-Management, Procedures, On Call Problem, Diseases and Drug. Vol. 5. New York: McGraw-Hill; 2004. p. 94-101.

8. Health Research Methodology (A Guide for Training in Research Methods). WHO; 2001;2:5-6.

9. Association of Indonesian Pediatricians. Textbook Neonatology. Jakarta: Association of Indonesian Pediatricians; 2010. p. 11-25.

10. Widarjono A. Applied Multivariate Analysis with SPSS, AMOS, and SMARTPLS Programs. Yogyakarta: UPP STIM YKPN; 2015. p. 89-90, 209-20. 